\section{Re: Den gamle mannen og frakken}

«Der jeg før så en senior, ser jeg nå en mentor,» skriver Lasse Pihlstrøm i Tidsskriftet nr. 2/2015 (1). Hans betraktninger om den gamle mannen og frakken bringer hans tanker tilbake til Homers epos Odyseen der Odyssev møter den «grånende mentor». Pihlstrøm skriver videre: «Vår kultur dyrker først og fremst ungdommen. I deler av arbeidslivet er det fleksibilitet, mobilitet, tempo og dynamikk som nå verdsettes høyest, fremfor klassiske verdier som erfaring, klokskap, lojalitet og stabilitet. Henger man ikke med i svingene, blir man fort sett på som gammel og avdanket.» Så føyer han til: «Svært sjelden har jeg hørt en kollega kalle en annen lege avdanket.»

Dette innlegget av Pihlstrøm er imponerende godt av en noe yngre lege. Han viser at kunnskaper ikke behøver å være til hinder for at man også kan ha forstand. Jeg føler imidlertid behov for å informere forfatteren om følgende: Norge, som det eneste landet i verden, fratar legene autorisasjon ved fylte 75 år - uten noen begrunnelse. Dette må bety at på dette tidspunkt i legekarrieren anses vi av norske helsemyndigheter for å være avdankete som leger. Annerledes er det vel ikke mulig og tolke dette. Det at avautoriseringen ikke begrunnes, betyr vel at det anses som unødvendig.

\section{Einar Skatteboe \\ einskat@online.no}

Einar Skatteboe (f. 1936) er spesialist i samfunnsmedisin og pensjonert lege.

Ingen oppgitte interessekonflikter

\section{Litteratur}

1. Pihlstrøm L. Den gamle mannen og frakken. Tidsskr Nor Legeforen 2015: 135: 162.

\section{Re: Cannabis som medisin}

Jørgen Bramness' kronikk om cannabis i Tidsskriftet nr. 3/2015 var interessant lesning (1), men behovet for at vi også her i Norge må prioritere mer forskning for at vi med større sikkerhet og kompetanse skal kunne ta i bruk cannabis som medisin, er oversett. Samtidig fremstår det for meg som om kulturelt betingede antakelser kanskje overskygger objektiviteten i enkelte påstander.

Det er lite som tilsier at cannabis i seg selv gir nevneverdig nedsatt helse eller økt risiko for sykdom hos brukeren. Det dokumenterte skadeomfanget er langt mindre enn de forbundet med lovlige rusmidler og medisiner med utstrakt bruk i samfunnet vårt, som f.eks alkohol, opiater eller benzodiazepiner (2). Moderne alternativer til røyking av cannabis, som spiselig ekstrakt og fordamping, reduserer også skadepotensialet. En studie har vist at kombinasjonen av opiater og fordampet cannabis kan redusere smerte hos kroniske smertepasienter (3). Kombinasjonen kan gi pasienten redusert opiatbehov og dermed færre bivirkninger.

Jeg mener det kulturelle stigmaet rundt denne planten har fătt mange lekmenn, helsepersonell og til og med forskere til å overføre aspekter av sykdomsbildet til individer som medisinerer/ruser seg på cannabis over på virkestoffet, uten noe medisinsk/farmakologisk grunnlag (4). Det er på tide at diskusjonen angående både medisinsk bruk og rekreasjonsbruk av cannabis kommer seg forbi fordommer som fortsatt preger den offentlige debatten, når fordommene i stadig økende forstand kan anses å være motbevist av den kumulative kunnskaps- og erfaringsbaserte litteraturen som er tilgjengelig i dag (5).

Jeg synes mye tyder på at stigmatisering, internerte misoppfatninger om psykofarmakologien og frykt for straff ved bruk av illegale rusmidler har en større innvirkning på individets psykiske helse enn rusmiddelet i seg selv. Et praktisk eksempel på skadevirkningen av forbudspolitikken i Norge er den medisinske bruken av morfin og ritalin, kontra ulovlig heroin og amfetamin, hvor skadevirkningene i større grad er til stede når produktet ikke er kvalitetssikret og titrering skjer ved risikabelt brukerutstyr og produkt med ukjent potens. Ved daglig bruk er den økonomiske belastningen i seg selv enorm.

Angående legaliteten til rusmidler, fra cannabis til opiater, er det fortvilende å se ordet «frislipp» i kontekst av legalisering/dekriminalisering. Det virker som om mange enda ikke vil innse at kriminalisering er det ultimate frislipp, på tross av den enorme svarte økonomien som omsetter ulovlige rusmidler for milliarder. Det er global tilgjengelighet $\mathrm{i}$ bygd og by av alle mulige mer eller mindre helseskadelige rusmidler uten restriksjoner for barn og ungdom. Udeklarerte produkter øker skadeomfanget av omtrent alle typer rusbruk, og fører til økt risiko sammenlignet med bruk av rusmidler med kjent styrke og renhet. Analyser av kloakken tyder på at forbudspolitikken ikke avskrekker (6), på tross av det mange vil klassifisere som umenneskelige høye strafferammer. Oftest rammer lovverket fattige og problematiske brukere, som med fordel kunne blitt møtt med økonomisk, medisinsk og psykiatrisk hjelp fremfor moralistiske sanksjoner som bøter og fengselsstraff.

\section{Brage Wollnick}

bwollnick@hotmail.com

Brage Wollnick (f. 1988).

Ingen oppgitte interessekonflikter.

Litteratur

1. Bramness JG. Cannabis som medisin. Tidsskr Nor Lægeforen 2015; 135: 252-3. 2. Nutt DJ, King LA, Phillips LD; Independent Scientific Committee on Drugs. Drug harms in the UK: a multicriteria decision analysis. Lancet 2010; 376: 1558-65.

3. Abrams DI, Couey P. Shade SB et al. Cannabinoid-opioid interaction in chronic pain. Clin Pharmacol Ther 2011; 90: 844-51.

4. DeRosse P, Kaplan A, Burdick KE et al. Cannabis use disorders in schizophrenia: effects on cognition and symptoms. Schizophr Res 2010: 120: 95-100.

5. The Drug Policy Alliance. 10 facts about marijuana. www.drugpolicy.org/ drug-facts/10-facts-about-marijuana (23.2.2015)

6. Thomas KV, Bijlsma L, Castiglioni $\mathrm{S}$ et al. Comparing illicit drug use in 19 European cities through sewage analysis. Sci Total Environ 2012; 432: 432-9.

\section{Re: Cannabis som medisin}

Takk til Bramnes for en informativ og fordomsfattig kronikk (1)! Det er på tide at det endocannabinoide nervesystemet blir aktualisert her til lands, og at cannabisplantens rolle og potensial som legemiddel blir belyst fra et farmakologisk perspektiv. Videre følger i all ydmykhet, et par tekniske korreksjoner:

Bramnes sier at det er urealistisk at cannabis vil bli tilgjengelig i norske og europeiske apotek, blant annet på grunn av manglende farmasøytisk kvalitet - dette på tross av at cannabismedisinen Sativex formidles via apotek i 17 europeiske land (2). I Nederland produseres fire varianter medisinsk cannabis (tørkede cannabisblomster med forskjellig THC/CBD-nivå) i regi av det statlige organet Het Bureau voor Medicinale Cannabis (BMC) (3). BMC fraråder imidlertid røyking av blomstene, og anbefaler en langt mindre skadelig inntaksmetode kalt «fordampning», hvor virkestoffene frigjøres ved lavere temperaturer uten den skadelige røyken som oppstår når plantematerialet brennes. De driver også egen forskning for å avklare skadepotensialet for denne metoden, sammenlignet med røyking.

Den uformelle praksisen foretrukket av mange medisinske brukere (legalt eller illegalt) er ikke å røyke, men å spise cannabisen. Virkestoffene i cannabisplanten er fettløselige og kan ekstraheres ved å legge blomstene i oppvarmet matolje/smør. Videre brukes fettekstraktet til matlaging, eller inntas direkte som man ville gjort med tran. Denne metoden eliminerer skadene knyttet til røyking (KOLS, kreft). Doseringen vil fortsatt være vanskelig å fastslå så lenge produktet ikke er testet og kommer uten varedeklarasjon. Nederland har langt på vei klart å løse dette problemet ved å produsere og teste sin egen cannabis. 